\title{
Analysis of the Contribution Rate of Human Capital Investment to Economic Growth in Shandong Province
}

\author{
Xiulin $\mathrm{Ji}^{1, \mathrm{a}}$, Meixia Shi ${ }^{2, \mathrm{~b}}$ \\ ${ }^{1}$ Beijing Jiaotong University, Beijing, China \\ ${ }^{2}$ Beijing Jiaotong University, Beijing, China \\ axiulin_ji@163.com, ${ }^{b}$ mxshi@bjtu.edu.cn
}

Keywords: Human capital, Health investment, Educational investment,Contribution rat.

\begin{abstract}
This paper discusses the impact of human capital investment on economic growth in Shandong Province. Through empirical research, it is found that the material capital stock is still the main factor driving the economic growth of Shandong Province. The increase of human capital stock in primary school, junior middle school and senior high school education has a significant positive effect on economic growth, while the increase of human capital stock in general higher education has a negative contribution. The reason for this phenomenon may be the brain drain caused by the "big province of college entrance examination". Therefore, we should take active measures to attract and retain talents.
\end{abstract}

\section{Introduction}

The World Bank's World Development Report 2019: A Change in the Nature of Work, published this year by the World Bank, argues that increasing investment in population health and education is a top priority in a rapidly evolving and increasingly technology-affected labor market. This shows that under the background of the rapid development of the current knowledge economy, the important role of human capital in the sustained and stable development of a country or region is becoming more and more prominent. Human capital is formed through human capital investment. Shandong Province, as a large population province in China, has abundant human resources, but human capital investment is at the middle and lower reaches of the country. Therefore, to fully understand the current situation of human capital investment, recognizing the lack of investment in human capital, and to increase the level of investment in human capital has important implications for future economic development in Shandong Province.

\section{Literature review}

Theodore W. Schultz, was the first man to explicitly propose the concept of "human capital" and studied the ways of human capital formation.There are education, health, on-the-job training, information on career opportunitie and migration ${ }^{[1]}$.After proposing the theory of human capital investment, schultz calculated the contribution of education investment, the most important investment in human capital investment, to the economic growth of the United States from 1929 to 1957 with the rate of return method, which was as high as $33 \%{ }^{[2]}$.Another Nobel prize-winning economist, Gary s. ecker, has driven the development of human capital even further by his microscopic analysis of its role in economic development. Denison Through the quantitative analysis of human capital elements, it is proved that $23 \%$ of the economic growth in the United States from 1929 to 1957 is attributed to the development of education ${ }^{[3]}$. The "new growth theory" represented by Paul Romer (1990) and Robert Lucas (1988) considers the factors of human capital ${ }^{[3]}$.

Many domestic scholars have also studied the impact of human capital on economic from different perspectives. From the perspective of human capital agglomeration, Xiang Deng et al. (2019) founded that there has a U-shaped relationship betwee the human capital and economic growth ${ }^{[4]}$. Yajing Bian (2004) empirically analyzed the impact of human capital on economic growth in eastern and western China $^{[5]}$. Jin Lu (2014) and Chao Ni (2017) analyzed the spatial role of human capital in economic 
growth $^{[6-7]}$. Dihai Wang (2015) analyzed the effect of health investment on economic growth by using transnational panel data. It was found that health expenditure and education expenditure had significant positive effects on economic growth, while the increase of health expenditure had significant negative effects on economic growth ${ }^{[8]}$.

\section{Empirical Strategy,Variables and Data}

\subsection{Model selection}

This paper uses the modified C-D production function as the measurement model.

$$
\mathrm{Y}_{\mathrm{t}}=\mathrm{A}_{\mathrm{t}} \times \mathrm{K}_{\mathrm{t}}^{\alpha} \times \mathrm{H}_{\mathrm{t}}^{\beta}
$$

In Equation (1), $\mathrm{Y}_{\mathrm{t}}$ refers to GDP, $A_{t}$ denotes comprehensive technical level, $K_{t}$ refers to the amount of material capital input, $H_{t}$ means the amount of human capital input, $\alpha 、 \beta$ is the elasticity index of physical capital input and human capital input respectively.

After the mathematical transformation of the model, the equation is obtained:

$$
\frac{\Delta Y_{\mathrm{t}}}{Y_{t}}=\frac{\Delta A_{t}}{A_{t}}+\alpha \frac{\Delta K_{t}}{K_{t}}+\beta \frac{\Delta H_{t}}{H_{t}}
$$

Where $d Y_{\mathrm{t}} / Y_{\mathrm{t}}$ represents the GDP growth rate for the t-year, $d Y_{\mathrm{t}} / Y_{\mathrm{t}}$ the material capital growth rate for the t-year; $d Y_{\mathrm{t}} / Y_{\mathrm{t}}$ the human capital growth rate for the $\mathrm{t}$-th year; and $\alpha, \beta$ denotes the elastic coefficient for the physical capital and human capital levels, respectively.

\subsection{Variables and Data}

\subsection{1 economic growth indicators}

This paper selects the GDP from 1998 to 2016 as the basic index to measure the economic growth. The original data came from Shandong Statistical Year Book (2017). In order to eliminate the impact of inflation, the GDP price index $(1998=100)$ is converted into the real GDP value of each year expressed by the 1998 constant price.

\subsubsection{Physical capital stock}

This paper draws on the perpetual inventory method adopted by many scholars to estimate the physical capital stock. The formula is:

$$
K_{t}=K_{\mathrm{t}-1} \times(1-\delta)+I_{t}
$$

Where $K_{\mathrm{t}}$ and $K_{\mathrm{t}-1}$ represent the material capital stock of stage $\mathrm{t}$ and $\mathrm{t}-1$ respectively, $I_{\mathrm{t}}$ is fixed assets investme, $\delta$ refers to depreciation rate, and the depreciation rate quoted in this article is $9.6 \%$, which was estimated by Zhang Jun, Wu Guiying(2004) ${ }^{[9]}$. The base material capital stock of the base year also uses the data estimated by Zhang Yong. In 2000, the physical capital stock of shandong province was 1,469.4 billion yuan (calculated at current prices).

\subsubsection{Human capital stock}

This thesis draws on Lisheng Shen and Yunfa's Zhu method of calculating human capital stock in the analysis of human capital and economic growth, that is, the labor human capital stock is the product of per capita education funds and education level. $H_{\mathrm{i}}(\mathrm{i}=1,2,3,4$ indicates elementary school level, junior high school level, senior high school level and general higher education level respectively) representing human capital stock. $C_{\mathrm{i}}$ indicates the per capita education funding for different educational levels. Generally speaking, a university-level workforce usually receives 6 years of primary education, 3 years of junior high school education, 3 years of high school education, and 4 years of university education.

The labor human capital stock of each primary level are, 


$$
\begin{gathered}
\mathrm{H}_{1}=6 \mathrm{C}_{1} \\
\mathrm{H}_{2}=6 \mathrm{C}_{1}+3 \mathrm{C}_{2} \\
\mathrm{H}_{3}=6 \mathrm{C}_{1}+3 \mathrm{C}_{2}+3 \mathrm{C}_{3} \\
\mathrm{H}_{4}=6 \mathrm{C}_{1}+3 \mathrm{C}_{2}+3 \mathrm{C}_{3}+4 \mathrm{C}_{4}
\end{gathered}
$$

Considering the desirability and accessibility of data, the education funding input data of all levels of education is replaced by the general public budget education business fees at all levels of education in this paper. Growth rates are calculated by subtracting the previous year's figures from the current year's figures and then dividing by the previous year's figures.

\section{Empirical Results}

After the model passes the stationarity test, the cointegration test and the error correction model, the

\begin{tabular}{|c|c|c|c|c|}
\hline Regression equation & (1) & (2) & \multicolumn{2}{|c|}{ (3) } \\
\hline Regression factor & Primary education & $\begin{array}{c}\text { Junior high } \\
\text { school education }\end{array}$ & $\begin{array}{l}\text { High school } \\
\text { education }\end{array}$ & $\begin{array}{c}\text { General higher } \\
\text { education }\end{array}$ \\
\hline time & $1999-2015$ & $1999-2015$ & \multicolumn{2}{|c|}{$1999-2015$} \\
\hline$\alpha$ & 0.83255 & 0.700573904 & \multicolumn{2}{|c|}{0.6995407393375506} \\
\hline$\beta$ & 0.203709 & 0.217536632 & 0.481137494 & -0.216458722 \\
\hline $\begin{array}{c}\text { Contribution rate of } \\
\text { physical capital }^{\text {a }}\end{array}$ & 1.085066912 & 0.913061753 & \multicolumn{2}{|c|}{1.303305402} \\
\hline $\begin{array}{c}\text { Contribution rate of } \\
\text { human capital }^{\mathrm{b}}\end{array}$ & 0.315668981 & 0.332924116 & 0.656908483 & -0.168718152 \\
\hline F statistic & 12.24841619 & 11.91987301 & \multicolumn{2}{|c|}{9.863425309} \\
\hline$R^{2}$ & 0.636333716 & 0.630018658 & \multicolumn{2}{|c|}{0.694766007} \\
\hline $\bar{R}^{2}$ & 0.584381389 & 0.577164181 & \multicolumn{2}{|c|}{0.624327393} \\
\hline
\end{tabular}
regression results are shown in Table 1

Table 1. Regression Analysis of the Contribution Rate of Human Capital to Economic Growth in Different Educational Levels in Shandong Province.

Note:1. $\alpha=$ human capital contribution coefficient, $\beta=$ material capital contribution coef ficient .

2. $\mathrm{a}=\alpha \times$ annual growth rate of physical capital at different educational levels $\times$ (average annual growth rate of GDP) ${ }^{-1}$.

3. $b=\beta \times$ annual growth rate of human capital at different educational levels $\times$ (average annual growth rate of GDP) ${ }^{-1}$.

From the equations (1) and (2), the basic education investment has a positive contribution on the economic development in Shandong Province, and the contribution coefficient of compulsory education investment to economic growth is 0.20 and 0.22 , respectively. The contribution coefficient of higher education investment is 0.48 , and its corresponding contribution rate is also lower than the contribution rate of high school education human capital stock to economic growth.From equation (3), the increase in human capital above the high school education level has a positive contribution on economic growth. However, the increase in human capital in general higher education (four years of university education) has a certain negative effect on economic growth. This is not the same as the results of many scholars. The analysis may be results to the fact that the migration rate of higher education is higher than the immigration rate in Shandong Province.

In addition, from these three regression models, the contribution coefficient of the material capital stock formed by material capital investment to the economy is far greater than the contribution coefficient brought by the increase of human resources. This shows that the current economic growth is mainly driven by the growth of physical capital in Shandong Province. 


\section{Conclusion and Policy Implication}

Based on panel data from 1998-2006, this paper has explored the contribution rate of human capital to economic.Using C-D product function,we obtain the following results.Compulsory education and high school education have a certain positive impact on economic development, while higher education has a negative effect.And the economic development is mainly driven by the stock of physical capital in Shandong Province.

Shandong Province is a province with a large population. It has abundant available population resources. We must actively use this advantage. On the one hand, it is necessary to increase investment in education funds and strengthen the awareness of human capital to determine the speed and quality of economic development. On the other hand, we must create a good employment and entrepreneurial environment, provide rich salary and superior living conditions. To reduce the brain drain, thus retaining the province's talents and attracting external talents.

\section{References}

[1] Schultz, T. Human capital. Beijing institute of economics press,1990.

[2] L. H. Shen, and Y. F. Zhu, Human Capital and Economic Growth Analysis. Social sciences academic press (China), 1999.

[3] G. Duan, Review of Human Capital Theory, Chinese Talents Magazine, vol.05, pp. 26-29, 2005.

[4] X. Deng, G. F. Zhu and C. L. Wan, The Threshold Effect of Human Capital on China's Economic Growth: From the Perspective of Human Capital Agglomeration, Inquiry into economic Issues, vol.05, pp. 173-181, 2019.

[5] Y. J. Bian and L. S. Shen, Empirical Analysis of the Impact of Human Capital on Economic Growth in East and West China, The Journal of Quantitative \& Technical Economics, vol.12, pp. 19-24,2004.

[6] N. Chao and D. H. Meng, Human capital, economic growth and spatial spillover effects: An empirical study based on provincial panel data from 1978 to 2015. Journal of Beijing Technology and Business University (Social Sciences), vol. 06, pp. 113-122,2017.

[7] D. H.Wang, X. W. Li and H. Liang. How Health Investment Affects Economic Growth: A Study from Multinational Panel Data. Economic Science, vol.01, pp. 5-17,2019.

[8] J. Zhang, G. Y. Wu and J. P. Zhang. Estimation of China's Provincial Material Capital Stock: 1952-2002. Economic Research, vol. 10, pp. 2004.

[9] Shandong Provincial Bureau of Statistics,1998-2016, China Statistical Yearbook 1998-2016, China Statistics Press.

[10]Ministry of Education of the People's Republic of China. Statistical Announcement on the Implementation of National Education Funds. China Statistics Press, 1998-2017. 